\title{
Preparation and characterization of $\mathrm{DLC} / \mathrm{SiO}_{2} / \mathrm{Al}_{2} \mathrm{O}_{3}$ nanofiltration membrane
}

\author{
JIN-SU JEONG ${ }^{1}$, CHURL-HEE CHO ${ }^{\dagger}$, JONG-OH KIM ${ }^{\ddagger}$, DONG-HUN YEO ${ }^{\#}$ \\ and WON-YOUL CHOI ${ }^{1, *}$ \\ ${ }^{1}$ Department of Metal and Materials Engineering, Gangneung-Wonju National University, Gangneung 210 702, Korea \\ ${ }^{\dagger}$ Graduate School of Green Energy Technology, Chungnam National University, Daejeon 305 764, Korea \\ † Department of Civil Engineering, Gangneung-Wonju National University, Gangneung 210 702, Korea \\ \# Advanced Materials Convergence Division, Korea Institute of Ceramic Engineering and Technology, Seoul 153801 , \\ Korea
}

MS received 12 July 2012; revised 27 September 2012

\begin{abstract}
High quality ceramic thin films were fabricated by thin film deposition process in semiconductor field in order to fabricate high performance carbon/ $\mathrm{SiO}_{2} / \mathrm{Al}_{2} \mathrm{O}_{3}$ membrane. $\alpha-\mathrm{Al}_{2} \mathrm{O}_{3}$ substrate was used as a supporting material. A severe thermal stress and rough surface for active ceramic top layer such as zeolite were observed. To overcome thermal stress, intermediate layer of $\mathrm{SiO}_{2}$ and diamond-like carbon (DLC) thin films were used. $\mathrm{SiO}_{2}$ and DLC thin films on porous alumina support were deposited using plasma-enhanced chemical vapour deposition (PECVD). Homogeneous and smooth surfaces and interfaces of DLC/SiO $/ \mathrm{Al}_{2} \mathrm{O}_{3}$ membrane were observed by FESEM. The phases of DLC and $\mathrm{SiO}_{2}$ thin films were identified by X-ray diffraction pattern. Gas permeabilities of the nanofiltration membrane with $\mathrm{DLC} / \mathrm{SiO}_{2} / \mathrm{Al}_{2} \mathrm{O}_{3}$ were observed at various annealing temperatures. Mixed gas permeability of the membrane with $1 \mu \mathrm{m}$-thick $\mathrm{SiO}_{2}$ and $2 \mu \mathrm{m}$-thick DLC thin film annealed at $200{ }^{\circ} \mathrm{C}$ was $\sim 18 \mathrm{ccm}$ at $1018 \mathrm{mb}$ back pressure.
\end{abstract}

Keywords. Thin films; DLC/SiO $2 / \mathrm{Al}_{2} \mathrm{O}_{3}$ membrane; nanofiltration.

\section{Introduction}

Nanofiltration membranes can be generally classified into two major groups of organic-polymeric and inorganicceramic membranes. Polymeric membranes have been commercially available in a lot of different polymeric materials such as polysulfone, cellulose acetate and polyamide. They are relatively easy to prepare and can be produced cheaply at large scale. However, their chemical stability is limited with respect to corrosive media, like strong acids and organic solvents (Mulder 1996; Hestekin et al 1999). The application is also limited to moderate temperature due to its thermal instability. In recent days, much research is focused on ceramic nanofiltration membranes. Ceramic membranes generally show high thermal, chemical and mechanical stabilities. They are expected to constitute a promising alternative for polymeric membranes (Burggraaf and Cot 1996; Gestel et al 2002, 2006).

High performance ceramic nanofiltration membrane can only be obtained in an asymmetric multilayer structure. The multilayer structure consists of supporting materials, mesoporous intermediate layers and microporous top layer. Alumina, titania, zironia and silica are considered as

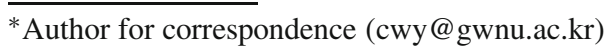

the main supporting materials for the formation of multilayer structures (Vacassy et al 1997; Luyten et al 2000; Benito et al 2004, 2005). Their preparation starts with the production of high quality supporting materials, because the performance of ceramic nanofiltration membrane is greatly influenced by the structural properties of supporting materials (Luyten et al 1997, 1999). The modification of intermediate layers is also very important for the preparation of top layer. The modification of intermediate layers with fine-grained mesoporous ceramic thin film is necessary in order to reduce the coarse pore of the supporting materials and large surface irregularities or defects. The preparation process generally includes a heating process such as sol-gel, hydrothermal and annealing. The heating process makes a cracking and infiltration from the difference of thermal expansion coefficient of supporting materials and top layer. To prevent cracking and infiltration, thermal expansion of intermediate layers is also considered. Especially, in case of alumina as a supporting material and zeolite as a top layer, the difference of thermal expansion coefficient is very large and it makes some defects in ceramic nanofiltration membrane. Because, thermal expansion coefficient of alumina and zeolite are $8.5 \times 10^{-6} \mathrm{~K}^{-1}$ and $2 \times 10^{-5} \mathrm{~K}^{-1}$, respectively, the intermediate layer having middle value between alumina and zeolite is needed to 
release thermal stress (Tschaufeser and Parker 1995; Bayuseno et al 1999).

To prevent cracking and infiltration resulting from thermal stress and shock in ceramic nanofiltration membranes, hydrogenated amorphous carbon (diamond-like carbon, DLC) of $2 \times 10^{-6} \mathrm{~K}^{-1}$ and silicon dioxide $\left(\mathrm{SiO}_{2}\right)$ of $5 \times 10^{-7} \mathrm{~K}^{-1}$ for intermediate layer have been used. DLC and $\mathrm{SiO}_{2}$ thin films with various thickness were prepared by plasma-enhanced chemical vapour deposition (PECVD). These films were annealed at several temperatures. Microstructure and phase with annealing temperature were observed by field emission scanning electron microscopy (FESEM) and X-ray diffraction pattern (XRD). Gas permeability was measured and the composition of mixed gas was analysed by gas chromatography (GC).

\section{Experimental}

\subsection{Support preparation}

To fabricate the support of $\alpha-\mathrm{Al}_{2} \mathrm{O}_{3}$ for nanofiltration membrane, $\mathrm{Al}_{2} \mathrm{O}_{3}$ powder of $0.5 \mu \mathrm{m}$ average diameter was used. $\mathrm{Al}_{2} \mathrm{O}_{3}$ powder was mixed with 2 wt $\% \mathrm{MC}$ solution. The disk-type alumina support of $2 \mathrm{~mm}$ thickness and $3 \mathrm{~cm}$ diameter was sintered at $1200{ }^{\circ} \mathrm{C}$ for $1 \mathrm{~h}$ by typical solid-state reaction. Surface morphologies of macroporous $\mathrm{Al}_{2} \mathrm{O}_{3}$ support were observed by field emission scanning electron microscopy (FESEM, Philips XL 30SFEG).

\subsection{Thin films preparation}

To reduce the residual stress of $\mathrm{SiO}_{2}$ thin film, low stress PECVD method was used. It is promising the low stress thin film by optimized plasma excitation frequency (Alayo et al 1998; Mackenzie et al 2005). The deposition temperature and $\mathrm{RF}$ power for $\mathrm{SiO}_{2}$ thin film were controlled $350{ }^{\circ} \mathrm{C}$ and $275 \mathrm{~W}$, respectively. Mass flows of $\mathrm{SiH}_{4}, \mathrm{~N}_{2} \mathrm{O}$ and $\mathrm{N}_{2}$

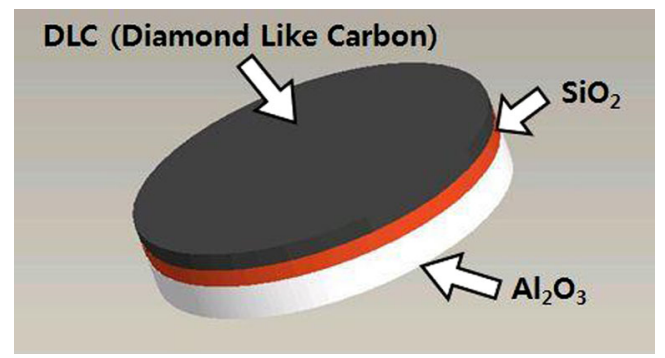

Figure 1. Schematic view of ceramic nanofiltration membrane of $\mathrm{DLC} / \mathrm{SiO}_{2} / \mathrm{Al}_{2} \mathrm{O}_{3}$ structures. source gases were 75,3300 and $1200 \mathrm{sccm}$, respectively. To increase the thickness of $\mathrm{SiO}_{2}$ thin film, the deposition time was increased and thickness of 1-4 $\mu \mathrm{m}$ was obtained. DLC thin film was also deposited by PECVD method and mass flow of source gas, $\mathrm{CH}_{4}$ was $40 \mathrm{sccm}$ in $10^{-5}$ torr vacuum chamber. The deposition temperature and RF power were $25^{\circ} \mathrm{C}$ and $0.74 \mathrm{~W}$, respectively. Low stress DLC thin film having $2 \mu \mathrm{m}$ thickness was obtained for $3 \mathrm{~h}$ by PECVD. Figure 1 shows schematic view of the ceramic nanofiltration membrane of $\mathrm{DLC} / \mathrm{SiO}_{2} / \mathrm{Al}_{2} \mathrm{O}_{3}$ multilayer structure.

\subsection{Characterization}

Microstructure of surfaces and interfaces of $\mathrm{DLC} / \mathrm{SiO}_{2} /$ $\mathrm{Al}_{2} \mathrm{O}_{3}$ membrane were observed by FESEM. The phases of DLC and $\mathrm{SiO}_{2}$ thin film were identified by XRD. To analyse the gas permeability, single gas of $\mathrm{He}$ and mixed gas of $40 \% \mathrm{CO}_{2}$ and $60 \% \mathrm{~N}_{2}$ were used. The ratio which is similar to the exhaust fumes of thermal power generator was selected. Gas permeabilities of the nanofiltration membrane with $\mathrm{DLC} / \mathrm{SiO}_{2} / \mathrm{Al}_{2} \mathrm{O}_{3}$ were observed at various annealing temperatures. Figure 2 shows diagram of the gas separation system.

\section{Results and discussion}

\subsection{Support and intermediate layers}

Supporting materials of $\mathrm{Al}_{2} \mathrm{O}_{3}$ powder was prepared and sintered by typical solid-state reaction. The disk-type $\mathrm{Al}_{2} \mathrm{O}_{3}$ support of $2 \mathrm{~mm}$ thickness and $3 \mathrm{~cm}$ diameter was fabricated. Figure 3(a) and (b) show top view and cross-sectional view of $\mathrm{Al}_{2} \mathrm{O}_{3}$ support, respectively. The average pore size from figure 3(a) was about $300 \mathrm{~nm}$. This macroporous structure was uniformly observed in figure 3(b) and was adequate to the supporting materials of nanofiltration multilayer membrane.

DLC and $\mathrm{SiO}_{2}$ thin films for multilayer nanofiltration membrane were deposited by PECVD. The nanofiltration membrane having $2 \mu \mathrm{m}$ thick DLC/1 $\mu$ m-thick $\mathrm{SiO}_{2} / \mathrm{Al}_{2} \mathrm{O}_{3}$

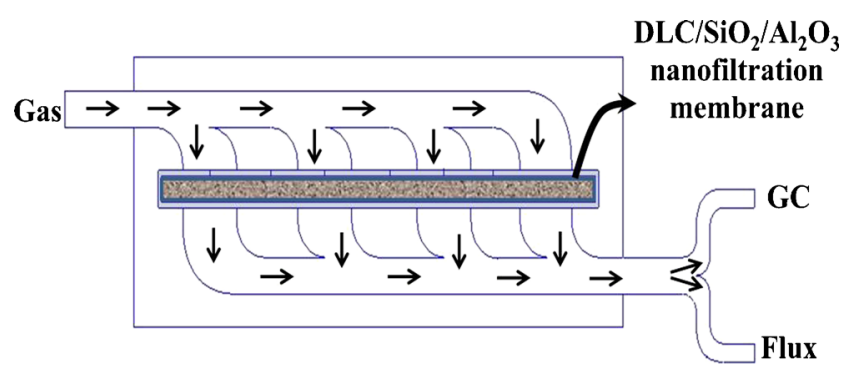

Figure 2. Diagram of gas separation system. 

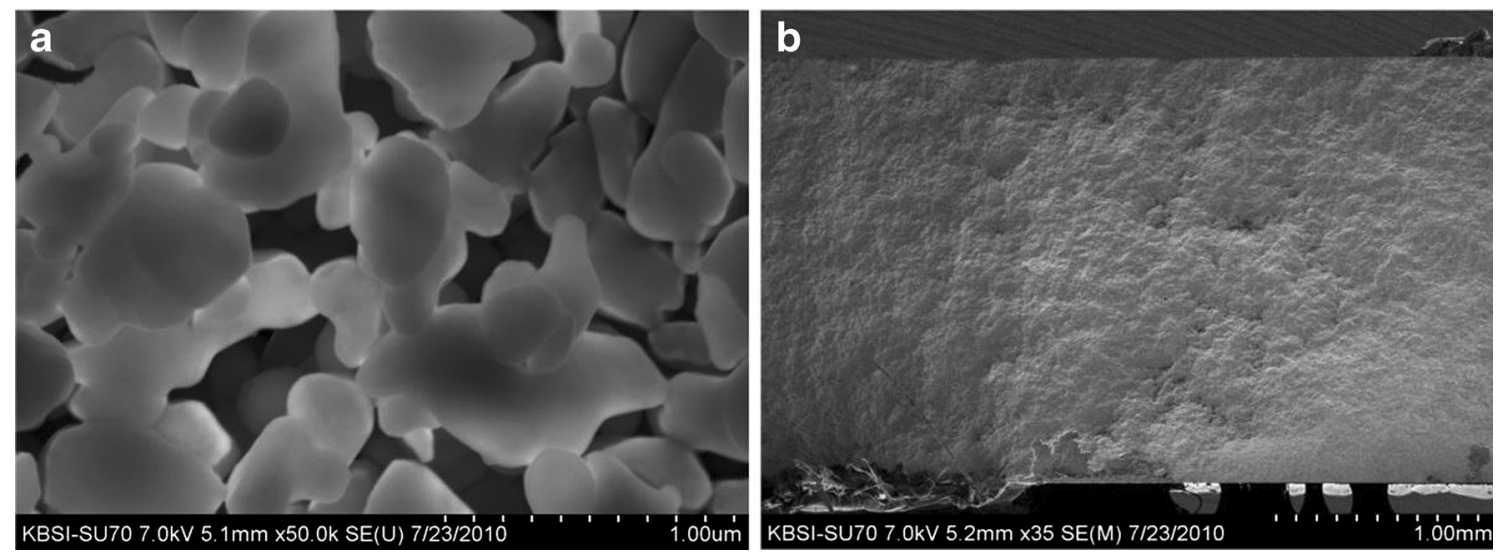

Figure 3. Microstructures of $\mathrm{Al}_{2} \mathrm{O}_{3}$ support by FESEM: (a) top view and (b) cross-sectional view.

structure was annealed at various temperatures of 200, 250 and $450{ }^{\circ} \mathrm{C}$. The microstructure of nanofiltration membrane was observed by FESEM. Figure 4(a) and (b) show top view and cross-sectional view of nanofiltration membrane without annealing, respectively. As-deposited DLC thin film has a grain size of $\sim 5 \mu \mathrm{m}$ and a very smooth surface morphology. The macrostructure of support was not observed due to microporous DLC thin film. To obtain the crystalline and more dense microstructure, $\mathrm{DLC} / \mathrm{SiO}_{2} / \mathrm{Al}_{2} \mathrm{O}_{3}$ nanofiltration membrane was annealed from $200-450{ }^{\circ} \mathrm{C}$. Figure 4(c), (e) and $(\mathrm{g})$ show top view of nanofiltration membrane at 200 , 250 and $450{ }^{\circ} \mathrm{C}$, respectively. Figure 4(d), (f) and (h) show the cross-sectional view of nanofiltration membrane at 200 , 250 and $450^{\circ} \mathrm{C}$, respectively. The grain size of DLC thin film was decreased with annealing temperature. DLC thin film was mostly removed at $450{ }^{\circ} \mathrm{C}$ and the surface of $\mathrm{SiO}_{2}$ thin film was shown in figure 4(g). The carbon in DLC thin film might be oxidized to carbon dioxide for annealing. Figure 5 shows energy dispersive X-ray spectroscopy (EDS) analysis data of figure 4(c). Carbon and silicon peaks were obtained from DLC and $\mathrm{SiO}_{2}$ thin film of nanofiltration membrane. Similar EDS data was observed at higher annealing temperature. Figure 6 shows XRD patterns of DLC/SiO $2 / \mathrm{Al}_{2} \mathrm{O}_{3}$ nanofiltration membrane annealed at $450{ }^{\circ} \mathrm{C}$. All peaks were from $\alpha-\mathrm{Al}_{2} \mathrm{O}_{3}$ support. It revealed that DLC and $\mathrm{SiO}_{2}$ thin films were amorphous. There is no evidence of grain growing and phase transitions resulting from the annealing process.

\subsection{Gas permeability}

The characterization of nanofiltration membrane was investigated by measuring the gas permeability and gas chromatography. To optimize the annealing temperature of $\mathrm{DLC} / \mathrm{SiO}_{2} / \mathrm{Al}_{2} \mathrm{O}_{3}$ nanofiltration membrane, gas permeability was observed on $\mathrm{He}$ single gas. Figure 7(a) shows gas permeability of nanofiltration membrane with $1 \mu \mathrm{m}$ thick $\mathrm{SiO}_{2}$ and $2 \mu \mathrm{m}$ thick DLC on $\mathrm{Al}_{2} \mathrm{O}_{3}$ support with annealing temperature. The back pressure was $1018 \mathrm{mb}$ on
He single gas at $70{ }^{\circ} \mathrm{C}$. Gas flux for nanofiltration membrane without annealing showed a very high permeability of $52 \mathrm{ccm}$. Gas flux with annealing temperature was increased from $18-45 \mathrm{ccm}$. This increasing gas flux with annealing temperature resulted from the oxidation of DLC thin film with annealing process. This result corresponds to the microstructure of figure 4(c), (e) and (g). The oxidation of DLC thin film makes an easy He gas transfer through $\mathrm{DLC} / \mathrm{SiO}_{2} / \mathrm{Al}_{2} \mathrm{O}_{3}$ nanofiltration membrane.

To optimize the thickness of $\mathrm{SiO}_{2}$ thin film, gas permeability was observed on $\mathrm{He}$ single gas at $70{ }^{\circ} \mathrm{C}$. Figure 7 (b) shows $\mathrm{He}$ gas permeability of $1,2,3$ and $4 \mu \mathrm{m}$ thick $\mathrm{SiO}_{2}$ thin films annealed at $200^{\circ} \mathrm{C}$. He gas flux was increased from 18 to $\sim 220 \mathrm{ccm}$ with the thickness of $\mathrm{SiO}_{2}$ thin film. Rough surface morphologies with increasing thickness of $\mathrm{SiO}_{2}$ thin film was observed by FESEM. Microstructural quality of DLC thin film on $\mathrm{SiO}_{2}$ thin film was affected by the surface of substrate, $\mathrm{SiO}_{2}$. The high gas flux in $4 \mu \mathrm{m}$ thick $\mathrm{SiO}_{2}$ can be expressed with low-quality DLC thin film resulting from rough surface of $\mathrm{SiO}_{2}$.

For application of thermal power plant, gas permeability was measured on mixed gas of $40 \% \mathrm{CO}_{2}$ and $60 \% \mathrm{~N}_{2}$. Figures 8(a) and (b) show gas flux with annealing temperature and thickness of $\mathrm{SiO}_{2}$ thin film, respectively. The influence of mixed gas flux with annealing temperature and thickness were similar to figure 7 of $\mathrm{He}$ single gas. The lowest gas flux of $\sim 18 \mathrm{ccm}$ was shown in $1 \mu \mathrm{m}$ thick $\mathrm{SiO}_{2}$ and $2 \mu \mathrm{m}$ thick DLC on $\mathrm{Al}_{2} \mathrm{O}_{3}$ annealed at $200{ }^{\circ} \mathrm{C}$. It reveals that proper annealing temperature and $\mathrm{SiO}_{2}$ thickness for $\mathrm{DLC} / \mathrm{SIO}_{2} / \mathrm{Al}_{2} \mathrm{O}_{3}$ were $200{ }^{\circ} \mathrm{C}$ and $1 \mu \mathrm{m}$, respectively. The composition of mixed gas flux was analysed by gas chromatography (GC). Figure 9 shows GC data of mixed gas flux passing through $1 \mu \mathrm{m}$ thick $\mathrm{SiO}_{2} / 2 \mu \mathrm{m}$ thick DLC/ $/ \mathrm{Al}_{2} \mathrm{O}_{3}$ nanofiltration membrane. The flux obtained from the mixed gas of $40 \% \mathrm{CO}_{2}$ and $60 \% \mathrm{~N}_{2}$ consisted of $13.64 \% \mathrm{CO}_{2}$ and $86.24 \% \mathrm{~N}_{2}$, respectively. The content of $\mathrm{CO}_{2}$ gas which has a large molecule size was decreased $\sim 26 \%$ in mixed gas and $\mathrm{CO}_{2}$ molecules were more difficult to pass through $1 \mu \mathrm{m}$ thick $\mathrm{SiO}_{2} / 2 \mu \mathrm{m}$ thick DLC/ 

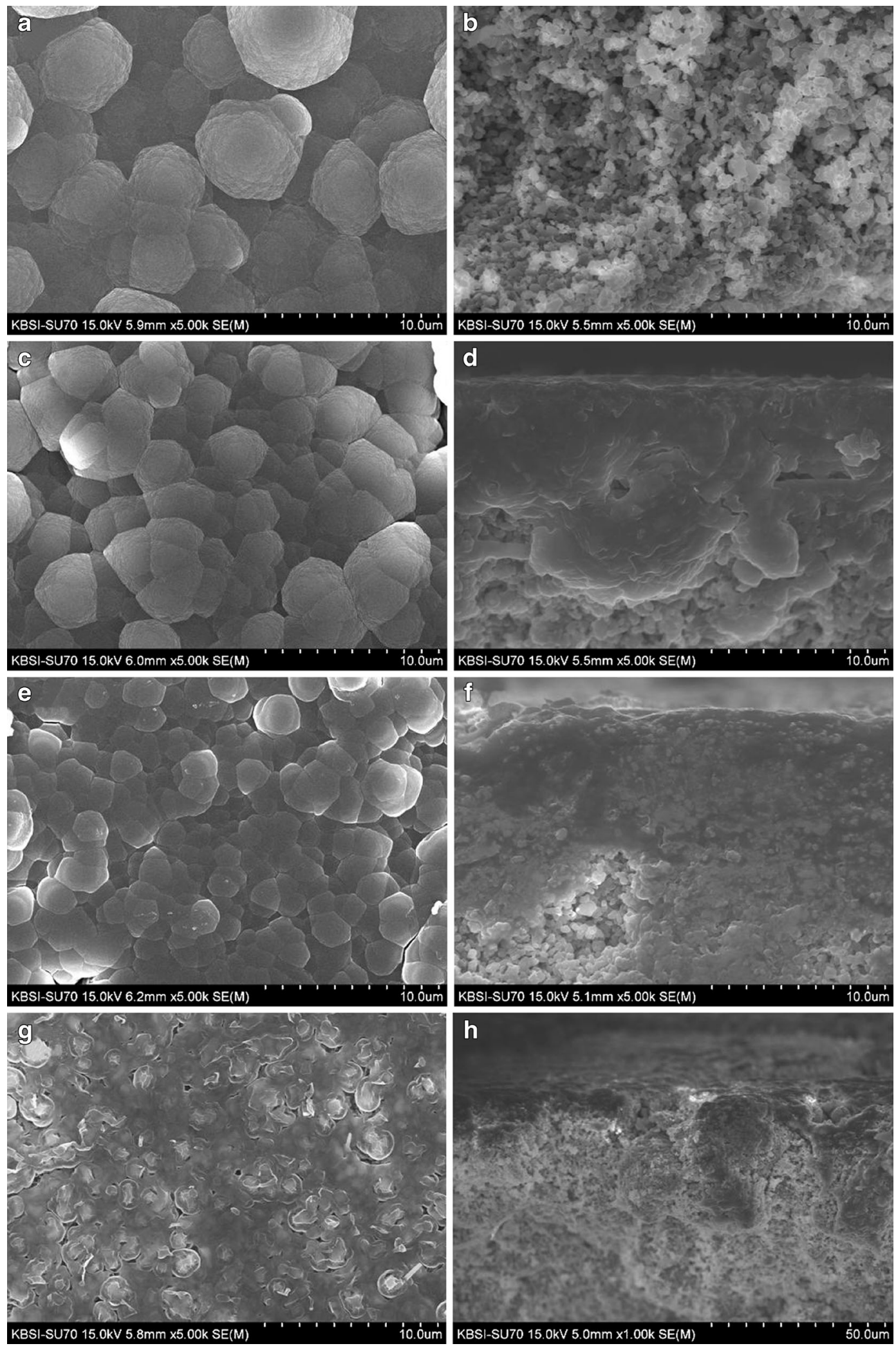

Figure 4. Microstructure of $1 \mu \mathrm{m}$ thick $\mathrm{SiO}_{2} / 2 \mu \mathrm{m}$ thick DLC/Al ${ }_{2} \mathrm{O}_{3}$ nanofiltration membrane at various annealing temperatures: (a) top view of membrane without annealing, (b) cross-sectional view of membrane without annealing, (c) top view of membrane annealed at $200{ }^{\circ} \mathrm{C}$, (d) cross-sectional view of membrane annealed at $200{ }^{\circ} \mathrm{C}$, (e) top view of membrane annealed at $250{ }^{\circ} \mathrm{C}$, (f) cross-sectional view of membrane annealed at $250{ }^{\circ} \mathrm{C}$, (g) top view of membrane annealed at $450{ }^{\circ} \mathrm{C}$ and (h) cross-sectional view of membrane annealed at $450{ }^{\circ} \mathrm{C}$. 


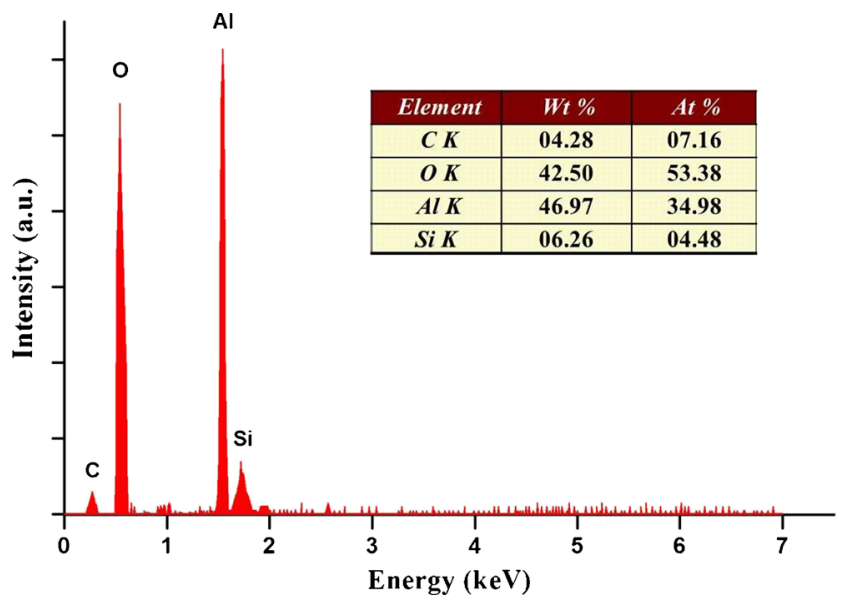

Figure 5. Energy dispersive X-ray spectroscopy (EDS) analysis data of figure 4(c).

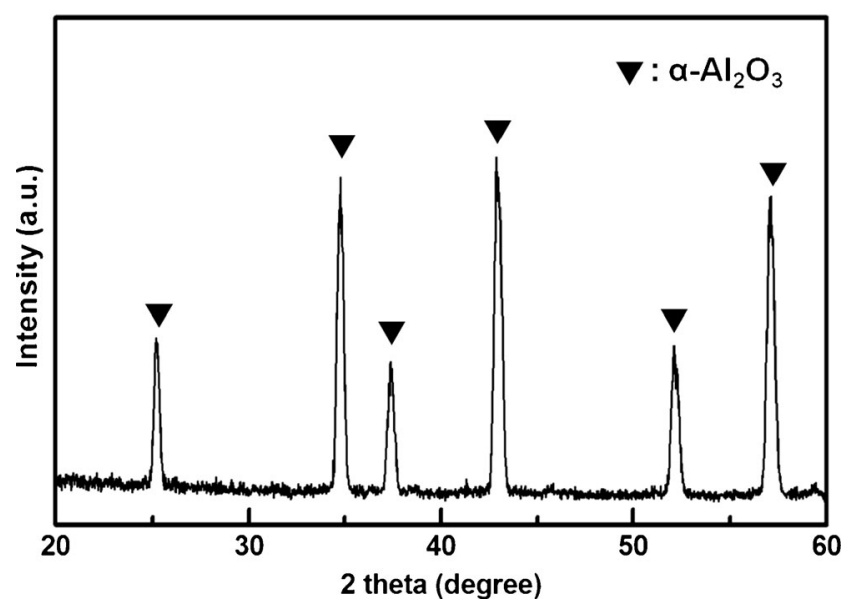

Figure 6. $\mathrm{XRD}$ patterns of $1 \mu \mathrm{m}$ thick $\mathrm{SiO}_{2} / 2 \mu \mathrm{m}$ thick DLC/ $/ \mathrm{Al}_{2} \mathrm{O}_{3}$ nanofiltration membrane annealed at $450{ }^{\circ} \mathrm{C}$.

$\mathrm{Al}_{2} \mathrm{O}_{3}$ nanofiltration membrane than $\mathrm{N}_{2}$ molecules. This nanofiltration property of $1 \mu \mathrm{m}$ thick $\mathrm{SiO}_{2} / 2 \mu \mathrm{m}$ thick DLC/Al ${ }_{2} \mathrm{O}_{3}$ will be useful for thermal power plant and car exhaust fumes.

\section{Conclusions}

Nanofiltration membrane with $\mathrm{DLC} / \mathrm{SiO}_{2} / \mathrm{Al}_{2} \mathrm{O}_{3}$ multilayer structure was fabricated and characterized. $\mathrm{Al}_{2} \mathrm{O}_{3}$ support was sintered by solid-state reaction and DLC and $\mathrm{SiO}_{2}$ thin films were deposited by PECVD. Gas permeability on annealing temperature and $\mathrm{SiO}_{2}$ thickness was investigated. The optimum annealing temperature and $\mathrm{SiO}_{2}$

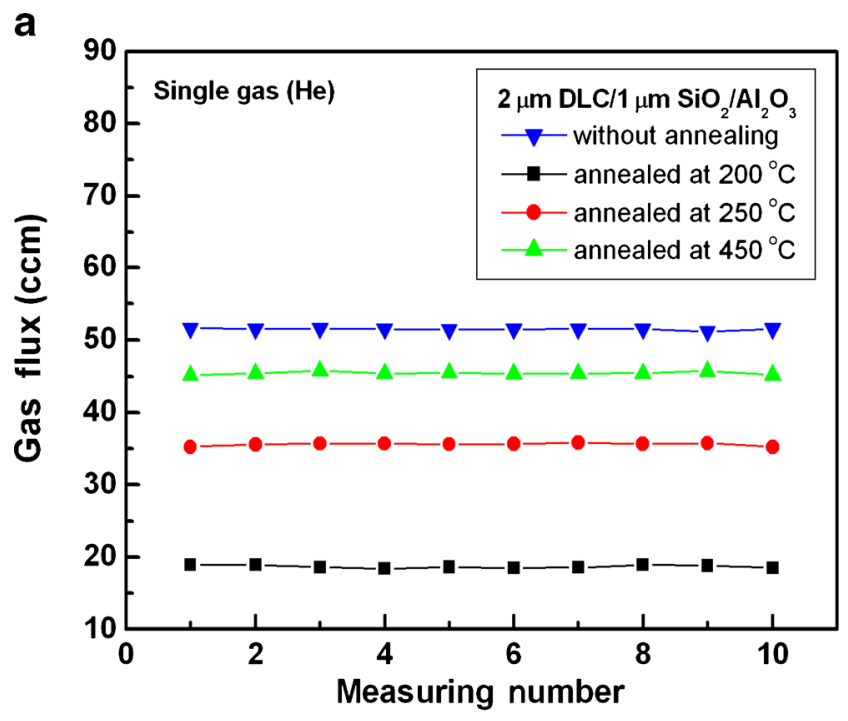

b

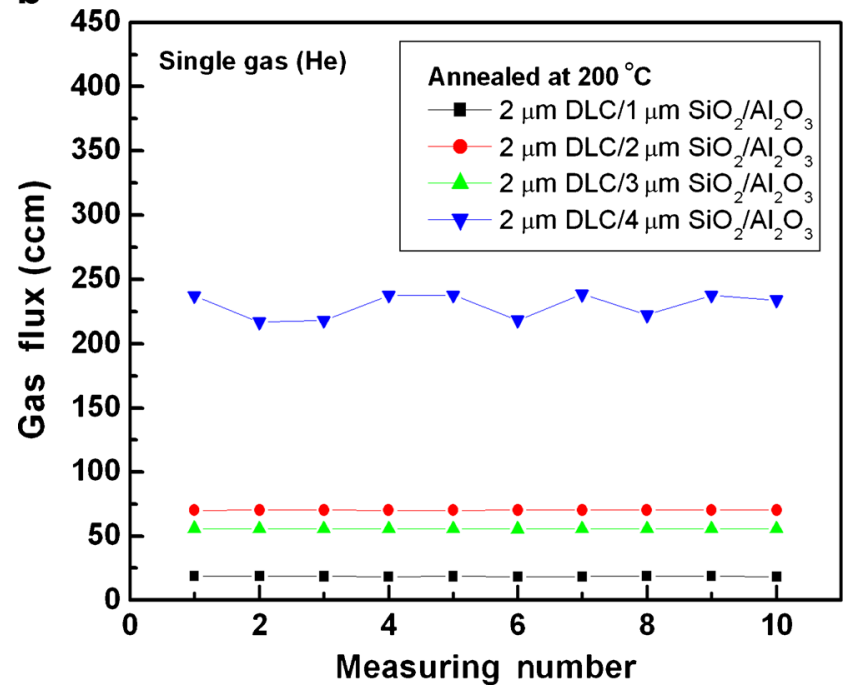

Figure 7. Single gas (He) permeability of $\mathrm{DLC} / \mathrm{SiO}_{2} / \mathrm{Al}_{2} \mathrm{O}_{3}$ nanofiltration membrane (a) gas flux of nanofiltration membrane with $2 \mu \mathrm{m}$ thick DLC/1 $\mu \mathrm{m}$ thick $\mathrm{SiO}_{2} / \mathrm{Al}_{2} \mathrm{O}_{3}$ at various annealing temperatures and (b) gas flux of $\mathrm{DLC} / \mathrm{SiO}_{2} / \mathrm{Al}_{2} \mathrm{O}_{3}$ nanofiltration membrane at various thickness of $\mathrm{SiO}_{2}$ thin films.

thickness were $200{ }^{\circ} \mathrm{C}$ and $1 \mu \mathrm{m}$, respectively. Gas permeability of mixed gas having $40 \% \mathrm{CO}_{2}$ and $60 \% \mathrm{~N}_{2}$ was observed and the flux was $18 \mathrm{ccm}$ at $1018 \mathrm{mb}$ back pressure. The flux consists of $13.64 \% \mathrm{CO}_{2}$ and $86.24 \% \mathrm{~N}_{2}$. It reveals that $\mathrm{CO}_{2}$ molecules were more difficult to pass through $1 \mu \mathrm{m}$ thick $\mathrm{SiO}_{2} / 2 \mu \mathrm{m}$ thick $\mathrm{DLC} / \mathrm{Al}_{2} \mathrm{O}_{3}$ nanofiltration membrane than $\mathrm{N}_{2}$ molecules. The nanofiltration properties of $\mathrm{DLC} / \mathrm{SiO}_{2} / \mathrm{Al}_{2} \mathrm{O}_{3}$ multilayer structure will be useful for thermal power plant and car exhaust fumes. 

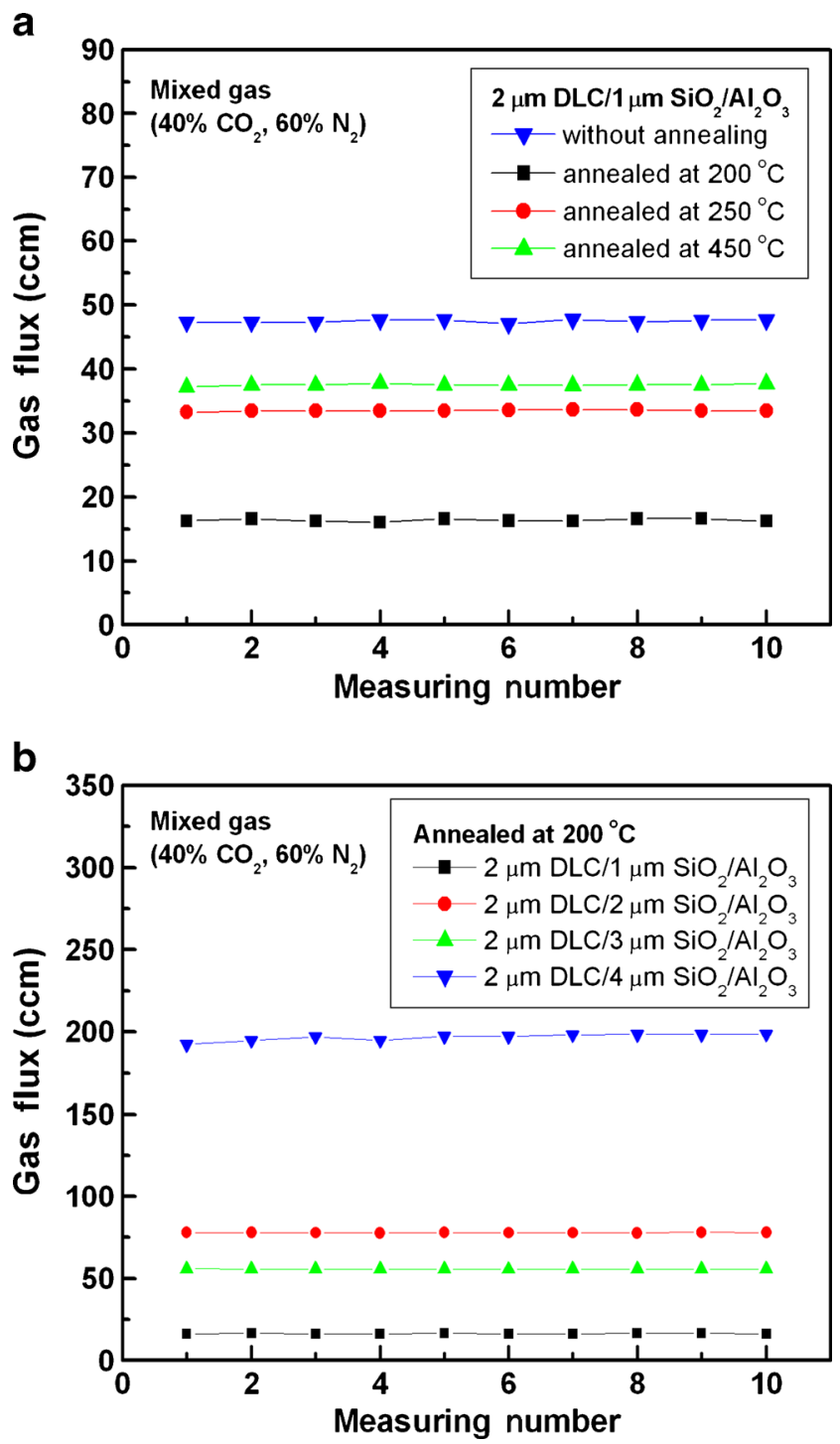

Figure 8. Mixed gas $\left(40 \% \mathrm{CO}_{2}\right.$ and $\left.60 \% \mathrm{~N}_{2}\right)$ permeability of $\mathrm{DLC} / \mathrm{SiO}_{2} / \mathrm{Al}_{2} \mathrm{O}_{3}$ nanofiltration membrane: (a) gas flux of the nanofiltration membrane with $2 \mu \mathrm{m}$ thick DLC/1 $\mu \mathrm{m}$ thick $\mathrm{SiO}_{2} / \mathrm{Al}_{2} \mathrm{O}_{3}$ at various annealing temperatures and (b) gas flux of $\mathrm{DLC} / \mathrm{SiO}_{2} / \mathrm{Al}_{2} \mathrm{O}_{3}$ nanofiltration membrane at various thickness of $\mathrm{SiO}_{2}$ thin films.

\section{Acknowledgments}

This research was financially supported by the Ministry of Education, Science Technology (MEST) and National Research Foundation of Korea (NRF) through the Human Resource Training Project for Regional Innovation (Grant No. 2012H1B8A2026009) and Korea CCS R\&D Centre (KCRC) funded by MEST of Korea (Grant No. 20120008912).

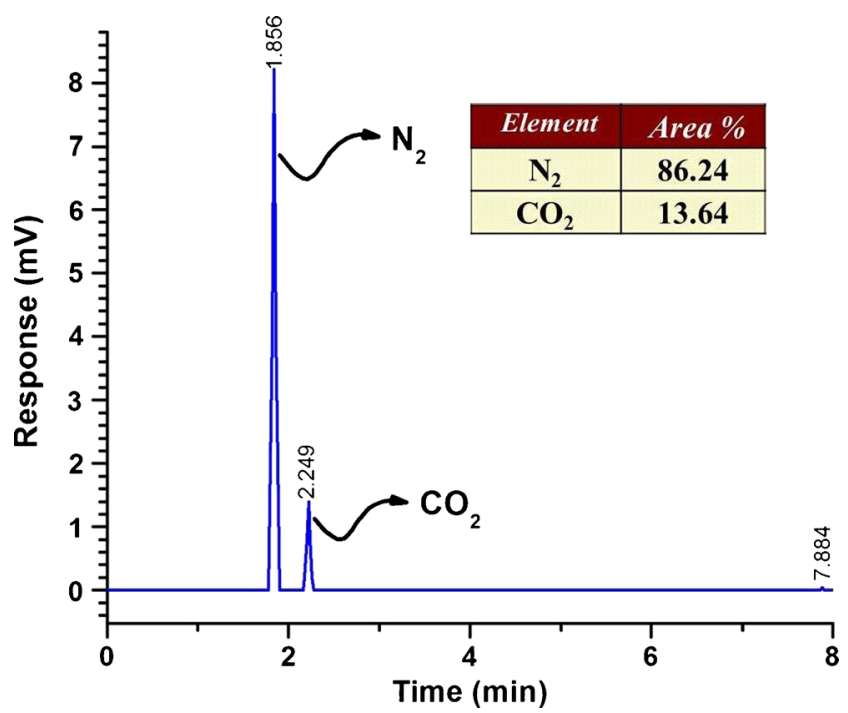

Figure 9. Gas chromatography (GC) data of mixed gas flux passed through $1 \mu \mathrm{m}$ thick $\mathrm{SiO}_{2} / 2 \mu \mathrm{m}$ thick $\mathrm{DLC} / \mathrm{Al}_{2} \mathrm{O}_{3}$ nanofiltration membrane.

\section{References}

Alayo M, Pereyra I and Carreno M 1998 Thin Solid Films 33240

Bayuseno A, Latella A and O'Connor B 1999 J. Am. Ceram. Soc. 82819

Benito J, Conesa A and Rodriguez M 2004 Bol. Soc. Ceram. 5821

Benito J, Conesa A, Rubio F and Rodriguez M 2005 J. Eur. Ceram. Soc. 251895

Burggraaf A and Cot L 1996 Fundamentals of inorganic membrane science and technology (Amsterdam, Holland: Elsevier)

Gestel T, Kruidhof H, Blank D and Bouwmeester H 2006 J. Membr. Sci. 284128

Gestel T, Vandecasteele C, Buekenhoudt A, Dotremont C, Luyten J, Leysen R, Bruggen B and Maes G 2002 J. Membr. Sci. 20773

Hestekin J, Smothers C, Bhattacharyya D, Ghorpade A and Hannah R 1999 Nanofiltration for removal of organics from aqueous and organic solvent streams, Dallas, TX, Presented at the 4th Topical conference on separations science \& technology, membrane separation in food and pharmaceutical

Luyten J, Cooymans J, Smolders C, Vercauteren S, Vansant E and Leysen R 1997 J. Eur. Ceram. Soc. 17273

Luyten J, Cooymans J, Adriansen W and Leysen R 1999 World ceramic congress on alternative process routes for better ceramic membrane supports, Florence, Italy, Presented at the 9th CIMTEC

Luyten J, Gestel T, Cooymans J and Smolders C 2000 Ceram. Trans. 115

Mackenzie K, Johnson D, Devre M, Westerman R and Reelfs B 2005 Electrochem. Soc. Proc. 1148

Mulder M 1996 Basic principles of membrane technology, (Dordrecht: Holland, Kluwer Academic) 2nd edn

Tschaufeser P and Parker S 1995 J. Phys. Chem. 9910609

Vacassy R, Guizard C, Thoraval V and Cot L 1997 J. Membr. Sci. 132109 